\title{
About the Artist: Mariquita "Micki" Davis
}

Micki Davis is a Chamorro video artist based in Los Angeles who also produces digital books, performances, sculptures, and gallery installations. After being awarded a BFA from the University of Georgia in 2006 and an MFA from the Visual Arts Department at the University of California-San Diego in $20 \mathrm{II}$, she has exhibited and collaborated on projects with artist collectives, museums, and publishers including Dashboard (Atlanta, GA); The Range (Saguache, Co); Oceanside Museum of Art (Oceanside, CA); and There Goes the Neighborhood (San Diego, CA).

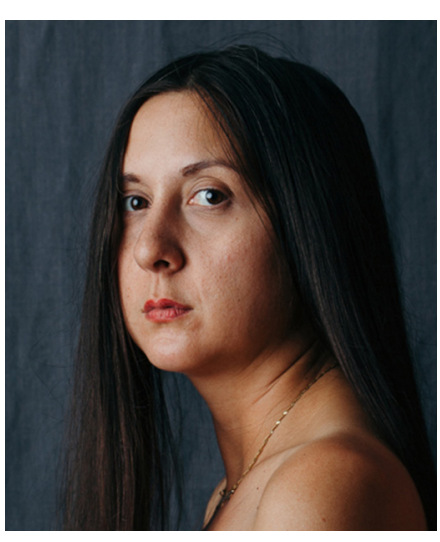

Рното By JoAnNe Kim

For the 2017 Honolulu Biennial, Davis's video Magellan Doesn't Live Here followed the construction of a replica sakman (ancient Chamorro sailing vessel) in California and its journey to Guam in time for the 2016 Festival of Pacific Arts. Offering insight into personal experiences of builders involved, including expressions of celebration and anxieties about returning home, this documentary also draws on the strength of their seafaring traditions and connections to the land and sea that define them. Her 20I I installation Close of Day drew audiences into a more performative engagement with ancestral practices and a social hour when families could reflect on past or present events and future possibilities. Conceived as a "visual fugue" with video projections, radios, a suspended tarpaulin roof, photographs, drinks, food, cards, and a table for audiences to gather around and chat, audience interactions in the gallery resonated with memories of social gatherings in Davis's grandparents' grocery store in Agat on Guam. Her 20I 4 digital publication Road Map of Guam for The St Claire (Philadelphia, PA), which combines video, text, and photographic imagery, represents a growing body of international artwork being created for dissemination and access online: http://the-st-claire.com/o2 I 5/postr.html

MOANA NEPIA

The art featured in this issue can be viewed in full color in the online versions. 


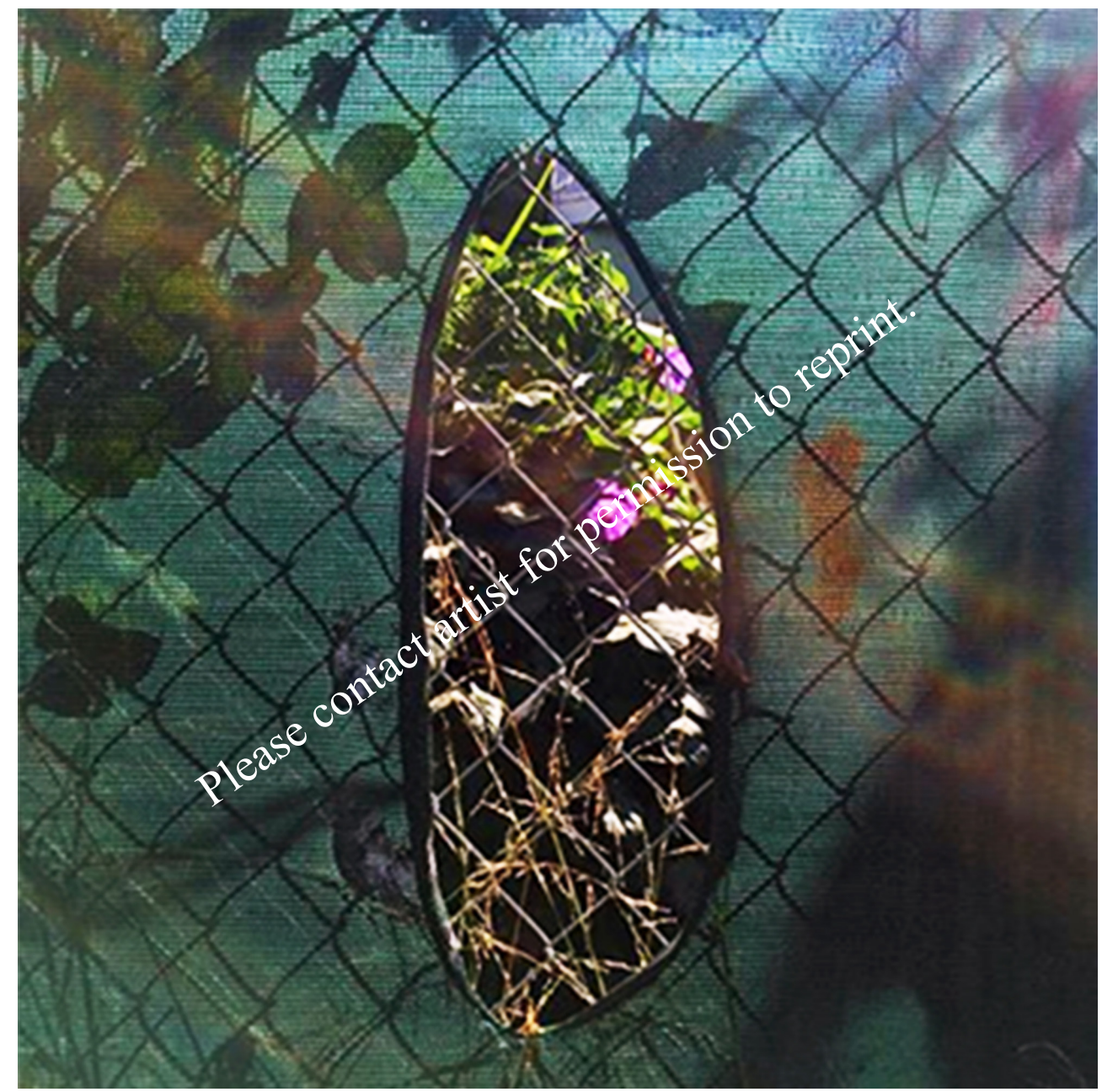

II.39pm 07/04/2017, by Micki Davis, 2017.

Instagram image from http://www.pictame.com/user/marimick/I 8 I 593209

Attuned to chance events and to the subtleties of color and composition that she observes in her daily life, Davis displays a painterly quality in her photography and film that is informed by both poetic and political sensitivities. In this image, torn shade cloth frames a tantalizing glimpse of fencedoff beauty within a delicate tracery of shadows and mesh. Suggestions of movement and restriction between different realms evoke the diasporic experience of self-imposed exile and enforced separations, alienation from ancestral homelands, and longing for reconnection against the backdrops of political uncertainty and increasing global insecurity. 


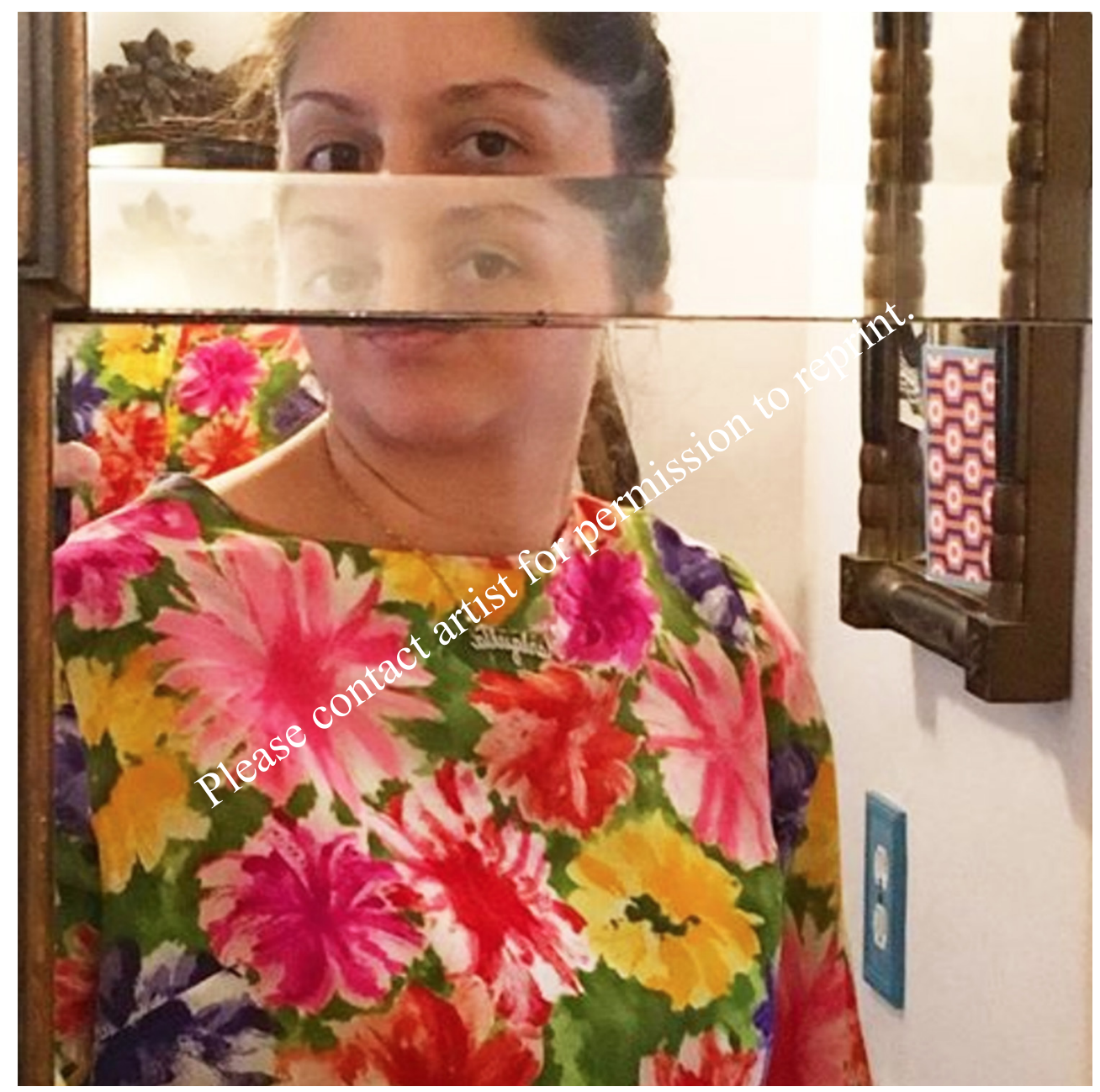

7:I8pm 04/I6/20I7, by Micki Davis, 2017.

Instagram image from http://www.pictame.com/user/marimick/I 8 I 593209

In the age of social media, where anyone with a cell phone or computer and Internet connection can create a global visual identity, artists and designers such as Micki Davis regularly share thoughts and images on platforms such as Instagram, offering snapshots of daily life and insights into current projects, working processes, and visual research. Sometimes these collections of images and text spawn other publications or provide motivation for gallery exhibitions. In other cases, the qualities of digital publication offer the most relevant option to an artist seeking to capture or enhance a sense of ephemerality, or an enigmatic, elusive, or momentary presence. 


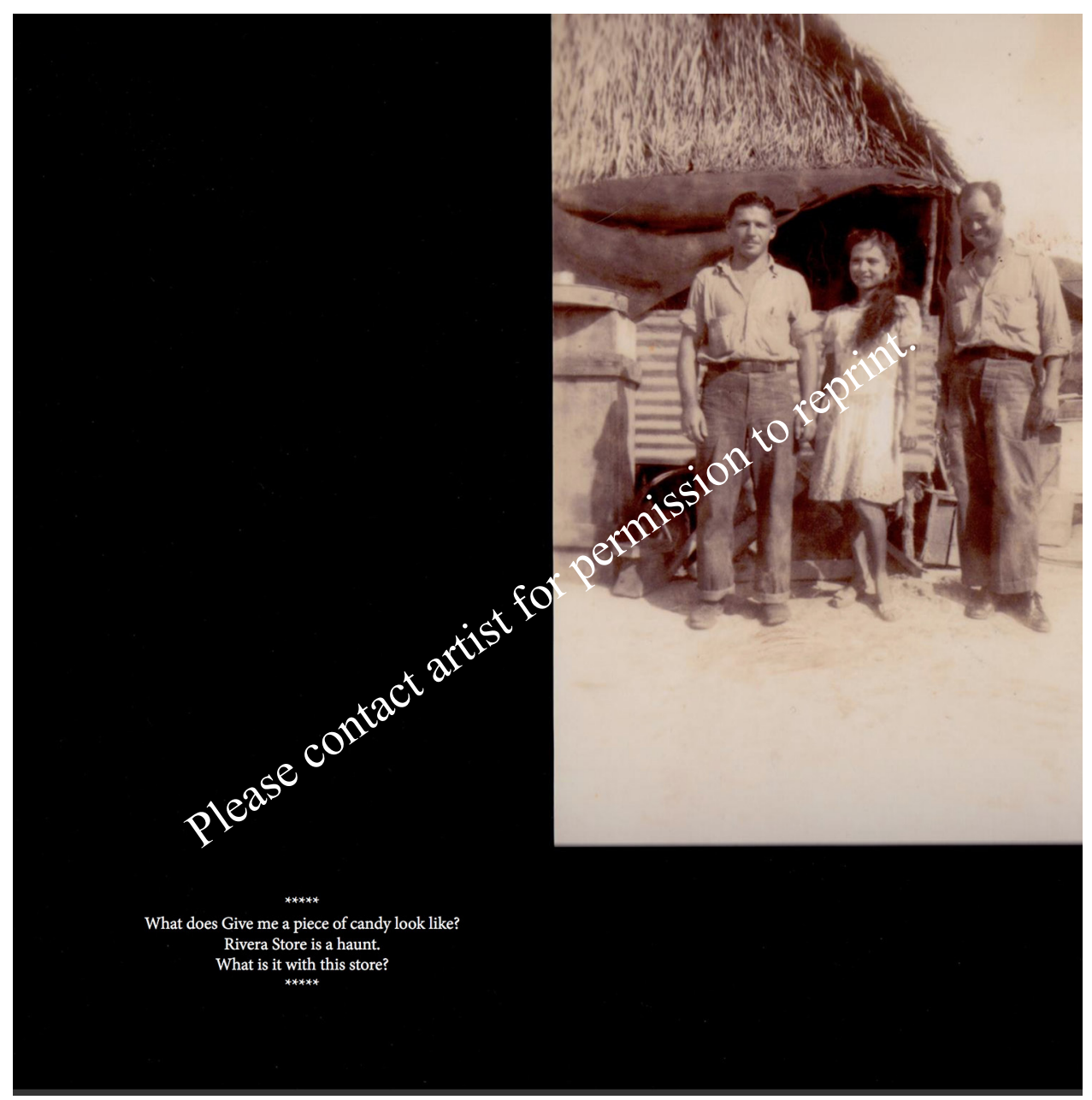

Close of Day, by Micki Davis, 2012.

Image from an e-book companion guide to a four-channel video installation and event: https://issuu.com/mickidavis/docs/closeofday_davis Family photographs of the artist's grandmother, Isabel Santos Rivera, outside the family store in Agat on Guam were included in the gallery installation Close of Day and in the e-book designed to document and accompany the exhibition. Compositional and choreographic sensibilities of the photographer and performance artist are extended here to the realms of typographic and spatial design-fragments of thought, questions, and voices from the past are spaced on pages to enhance feelings of absence and presence, separation, connection, memory, and loss. 


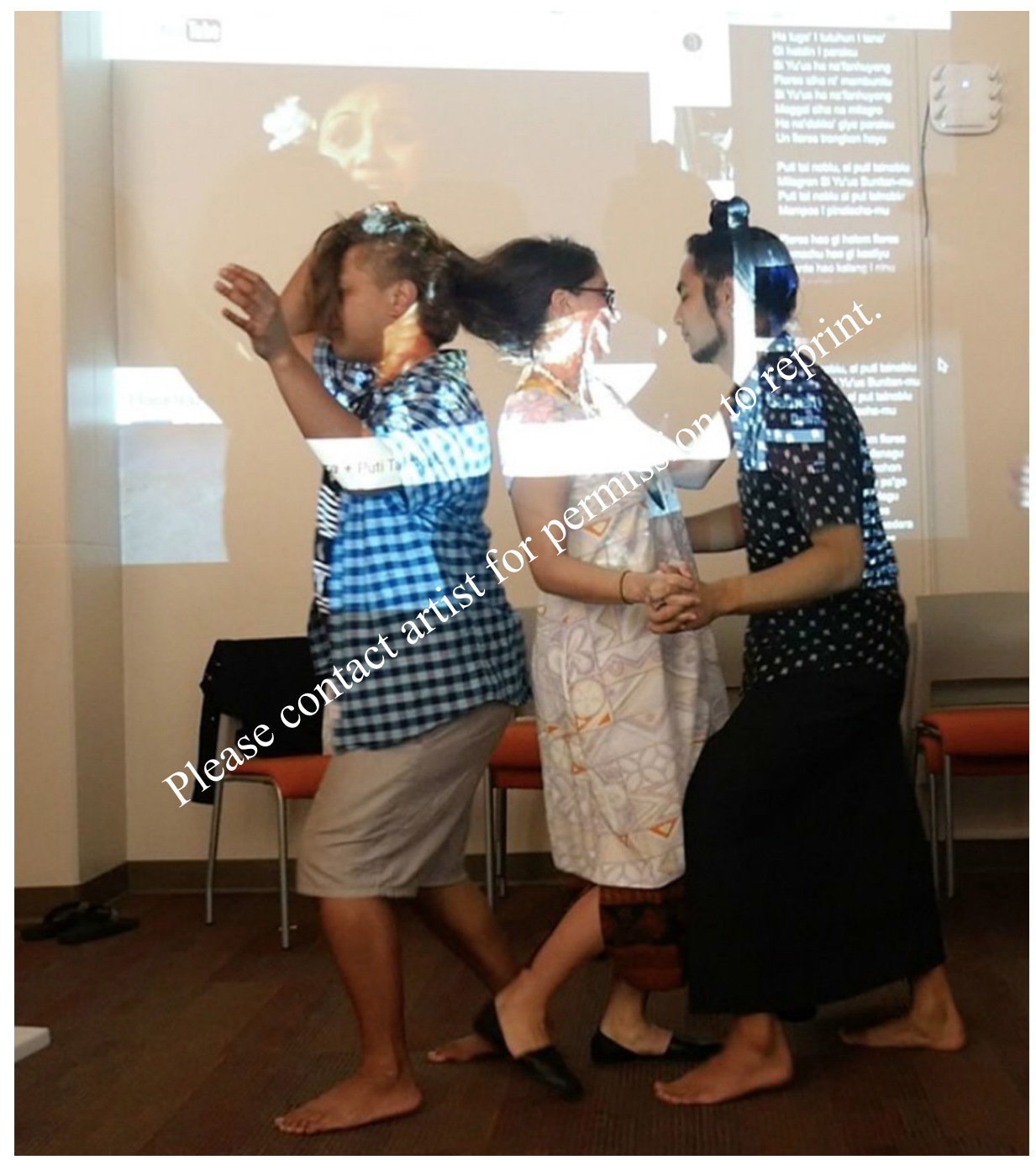

Performance photograph (detail) from homeLA Process Record (blog), 23 September 2016: http://www.homela.org/process-record/

Increasingly, Indigenous networks of visual and performing artists, such as I Moving Lab in Los Angeles, provide platforms for contemporary Indigenous artists to collaborate and disseminate their work in global contexts and communities outside the traditional art-world parameters of festivals, galleries, and museums. During rehearsals for her performance work $I$ bid you farewell flowers (how our stories are so much alike), Micki Davis joined choreographers Jack Gray (New Zealand/Aotearoa) and Dåkot-ta Alcantara-Camacho (Guam/USA) for a workshop with I Moving Lab, where she enticed them to join her in an impromptu performance of the cha-cha that she was rehearsing for her own production. 


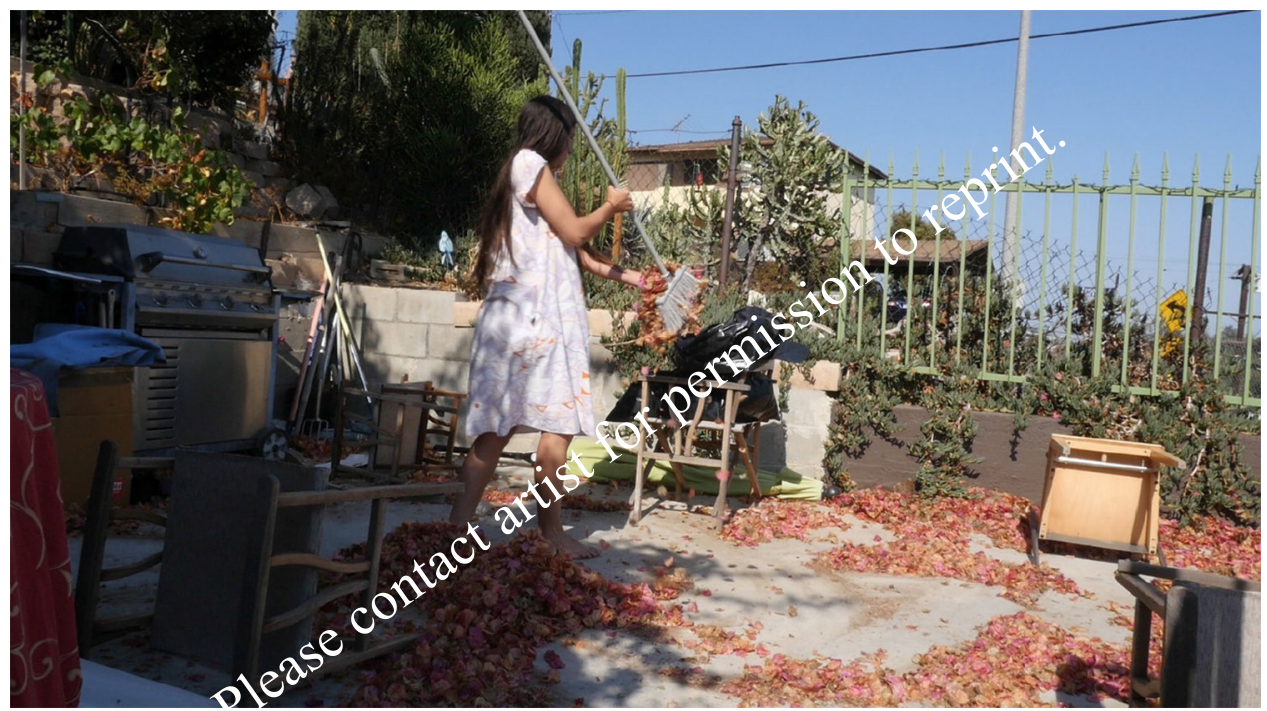

I bid you farewell flowers (how our stories are so much alike), by Micki Davis, 2016.

Image from homeLA Process Record (blog), 23 September 20I6: http://www.homela.org/process-record/

This blog documents ideas behind site-specific domestic performances coordinated by homeLA, including one that Davis devised in response to a conversation with a homeowner about the performance of vigils, her connections to the house, its history, and the death of a previous owner at the hands of his abused children. Bougainvillea, which dominates the gate and patio, is known to Chamorros as Puti Tai Nobiu, which translates as "It hurts not to have a lover." A song with this title by Chamorro singer/songwriter Flora Baza Quan was featured in the twenty-minute performance when Davis invited members of the audience to join her in a performance of the cha-cha. 


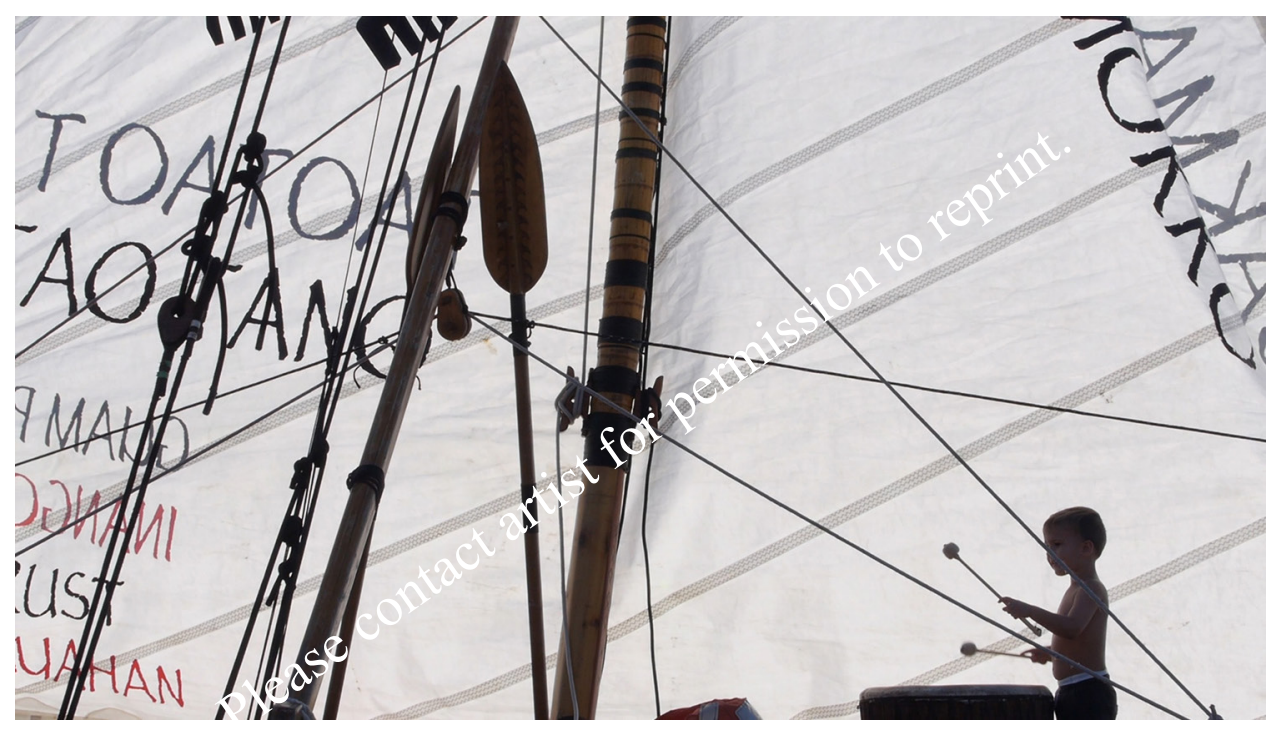

Magellan Doesn't Live Here, by Micki Davis, $20 \mathrm{I} 7$.

Video still.

[aga'ga': what we inherit what is passed from

contours the lines

of the sakman

as [riñón: the saltwind trades

in things unknown and unpredictable-

even without the names of the stars in chamorro-

even when we lost

contact-it will never be too dark

for us to see-

Excerpt from the poem "ginen aerial roots," by Craig Perez Santos.

Reproduced courtesy of Santos from his collection From Unincorporated

Territory [saina] (Oakland, CA: Omnidawn Publishing, 20ıо). 


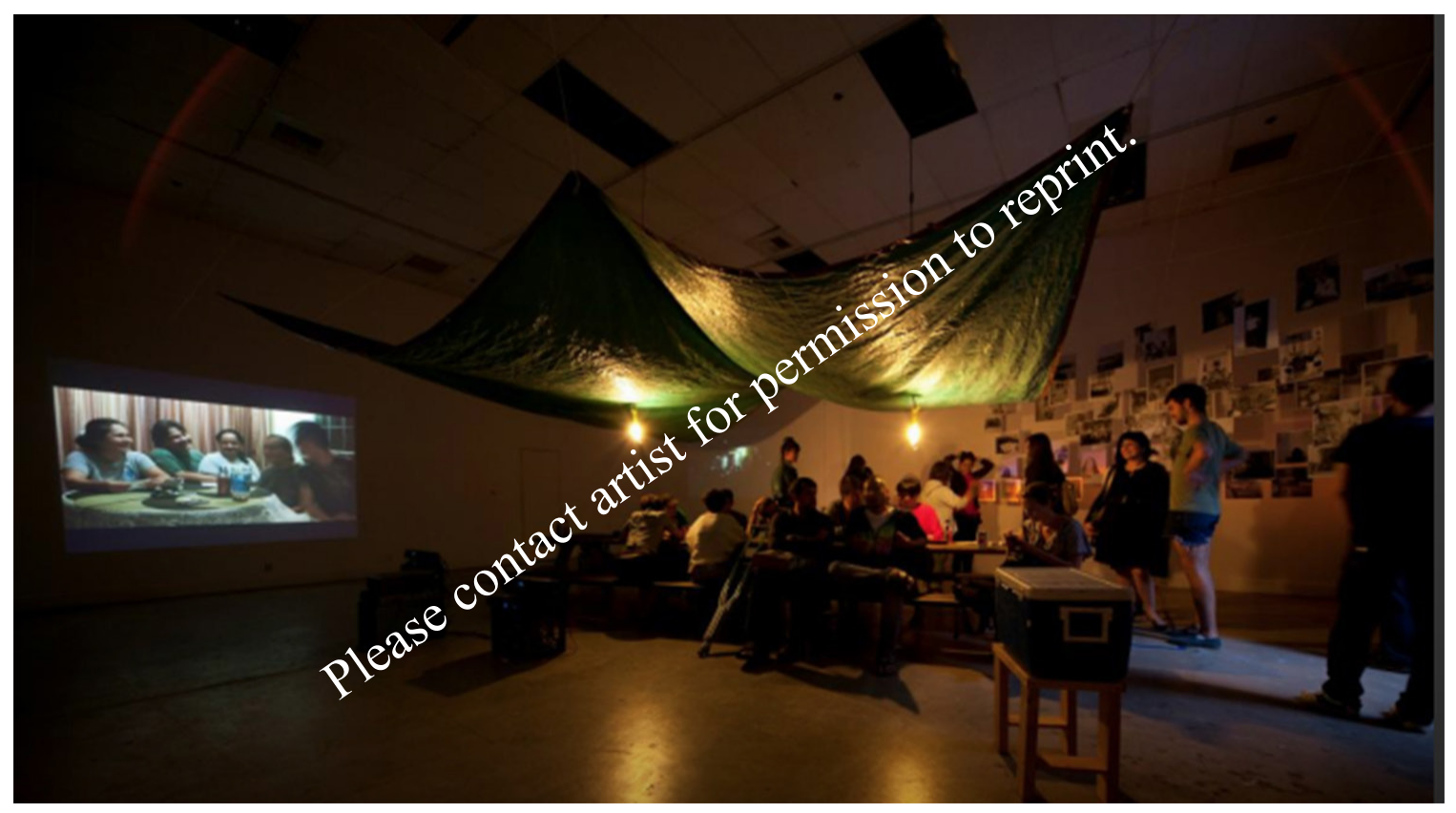

Close of Day, by Micki Davis, 2012.

Image from an e-book companion guide to a four-channel video installation and event: https://issuu.com/mickidavis/docs/closeofday_davis

Lighting, video projections, furniture, family photographs, and food helped to create a relaxing space for audience participation in an installation that Davis devised in response to memories of her grandparents' grocery store in Agat on Guam, which provided a focal point for local community interaction. The artist's dramaturgical and scenographic approach to curating this project shifts audience focus from viewing installation elements as visual art objects to perceiving them as sensory, emotional, and intellectual props or prompts for stimulating conversation and reflecting on the performative nature of community. The audience members become actors within a gallery that is less an exhibition venue and more a collaborative site for activation and performative engagement with ideas. 